The INL is a

U.S. Department of Energy

National Laboratory

operated by

Battelle Energy Alliance

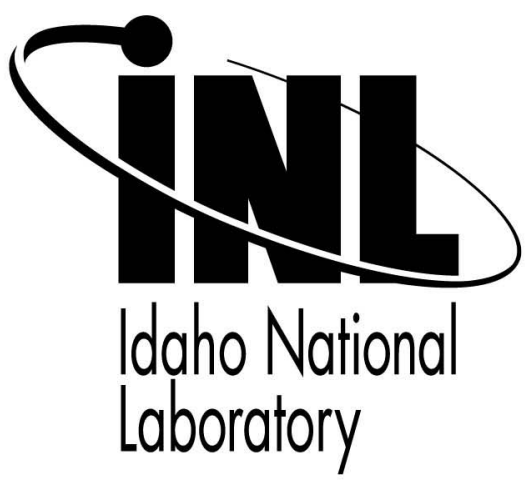

\title{
Effect of Process Variables During the Head-End Treatment of Spent Oxide Fuel
}

\section{International Pyroprocessing Research Conference}

B. R. Westphal

K. J. Bateman

C. D. Morgan

J. F. Berg

P. J. Crane

D. G. Cummings

J. J. Giglio

M. W. Huntley

R. P. Lind

D. A. Sell

\section{August 2006}

This is a preprint of a paper intended for publication in a journal or proceedings. Since changes may be made before publication, this preprint should not be cited or reproduced without permission of the author. This document was prepared as an account of work sponsored by an agency of the United States Government. Neither the United States Government nor any agency thereof, or any of their employees, makes any warranty, expressed or implied, or assumes any legal liability or responsibility for any third party's use, or the results of such use, of any information, apparatus, product or process disclosed in this report, or represents that its use by such third party would not infringe privately owned rights. The views expressed in this paper are not necessarily those of the United States Government or the sponsoring agency. 
Title: Effect of Process Variables During the Head-End Treatment of Spent Oxide Fuel

Authors: B.R. Westphal, K.J. Bateman, C.D. Morgan, J.F.Berg, P.J. Crane, D.G. Cummings, J.J. Giglio, M.W. Huntley, R.P. Lind, and D.A. Sell

Contact Address: $\quad$ Brian R. Westphal

Idaho National Laboratory, MS6180

P.O. Box 1625

Idaho Falls, ID 83415

(208) 533-7398

brian.westphal@inl.gov

Pages: 19

Tables: 0

Figures: 7 


\section{ABSTRACT}

The development of a head-end processing step for spent oxide fuel that applies to both aqueous and pyrometallurgical technologies is being performed by the Idaho National Laboratory, the Oak Ridge National Laboratory, and the Korean Atomic Energy Research Institute through a joint International Nuclear Energy Research Initiative. The processing step employs high temperatures and oxidative gases to promote the oxidation of $\mathrm{UO}_{2}$ to $\mathrm{U}_{3} \mathrm{O}_{8}$. Potential benefits of the head-end step include the removal or reduction of fission products as well as separation of the fuel from cladding. The effects of temperature, pressure, oxidative gas, and cladding have been studied with irradiated spent oxide fuel to determine the optimum conditions for process control. Experiments with temperatures ranging from $500^{\circ} \mathrm{C}$ to $1250^{\circ} \mathrm{C}$ have been performed on spent fuel using either air or oxygen gas for the oxidative reaction. Various flowrates and applications have been tested with the oxidative gases to discern the effects on the process. Tests have also been performed under vacuum conditions, following the oxidation cycle, at high temperatures to improve the removal of fission products. The effects of cladding on fission product removal have also been investigated with released fuel under vacuum and high temperature conditions. Results from these experiments will be presented as well as operating conditions based on particle size and decladding characteristics. 


\section{INTRODUCTION}

A head-end processing step is being developed for the treatment of spent oxide fuel by either aqueous or pyrometallurgical technologies [1-2]. The head-end step is based on previous investigations [3-4] and employs high temperatures to promote the oxidation of $\mathrm{UO}_{2}$ to $\mathrm{U}_{3} \mathrm{O}_{8}$ via an oxygen carrier gas. Potential benefits of the technology include the removal of volatile fission products and the separation of fuel from cladding to assist downstream processes.

During oxidation, the spent fuel experiences a $30 \%$ increase in lattice structure volume resulting in an expansion internally that stresses the cladding, allowing fission products and fuel to be separated from the cladding. The release of fission products occurs either directly from the broken fuel structure or following oxidation as volatile species. The head-end removal or reduction of fission products would simplify the overall flowsheets for both aqueous and pyrometallurgical processes. In addition, separating or decladding the fuel could simplify downstream processing steps while improving the dissolution kinetics of the fuel.

The research program at the Idaho National Laboratory (INL) has been termed DEOX for its initial emphasis on decladding via oxidation. Following an initial exploratory phase, where the objective was the investigation of fuel-clad separation and particle size, the program has progressed to a phase more applicable to advanced flowsheet development, i.e. the removal and collection of fission products. Testing with irradiated spent oxide fuel has been performed under varying operating conditions to assess the effects on fission product removal. Test variables included temperature, pressure, oxidative gases, and cladding. 


\section{EXPERIMENTAL}

The equipment utilized for testing consists of a fuel containment vessel, a cylindrical furnace capable of operation to $1050^{\circ} \mathrm{C}$, and a gas delivery/collection system, see Fig 1. The containment vessel has been specifically adapted for this program so that both a vacuum can be applied and oxidative gas can be regulated during a run. A more detailed description of this equipment can be found elsewhere [5].

Irradiated testing with spent oxide fuel is performed in the Hot Fuel Examination Facility (HFEF) located at the INL. The HFEF is an inert shielded hot cell requiring remote-handled operations. With the exception of the oxidative gas cylinder, all the components of the equipment are located in the HFEF argon cell.

The spent oxide fuel used for testing originated from the Belgium Reactor-3 (BR-3), a pressurized water reactor located in Mol, Belgium. The BR-3 fuel tested has a typical burnup of $\sim 37$ $\mathrm{GWd} / \mathrm{t}$ with a 25 year decay time and zircaloy-4 type cladding.

Segments of approximately $2.5 \mathrm{~cm}$ in length are sectioned from a BR-3 spent oxide fuel rod and loaded into a stand that keeps the segments vertical while processing. The stand is then placed into an alumina crucible and loaded into the fuel containment vessel and furnace. The nominal batch size is $100 \mathrm{~g}$ of fuel and cladding. Heating of the fuel commences either with or without an oxidative cover gas to a temperature between $500-700^{\circ} \mathrm{C}$. If the oxidative gas, either oxygen or air, has not been supplied from the start, it is applied at the maximum temperature between $500-700^{\circ} \mathrm{C}$. A duration of 1-2 hours for the oxidative gas and flowrates on the order of $0.51 /$ min have been utilized during the oxidation cycle. If a higher temperature or lower pressure test is being performed, those conditions are applied following the sequence given. 
Following a test, fuel that has been removed from the cladding is characterized and sampled for chemical analyses. Typical chemical analyses performed on the spent oxide fuel include ICPOES, ICP-MS, gamma spectroscopy, and Leco for oxygen analyses. Identical chemical analyses have been performed on fuel samples prior to testing so that a comparison can be made of fission product content.

\section{RESULTS AND DISCUSSION}

Results from tests performed with the BR-3 spent oxide fuel include particle size measurements, conditions for fuel separation from the cladding, and the extent of fission product offgassing. Off-gassing of fission products is measured by comparing the chemical analyses of fuel samples taken both before and after the oxidation cycle, then calculating fission product removal.

\section{III.A. Measurement of Particle Size}

Several tests have been performed for the determination of fuel particle size following an oxidative decladding cycle. Given in Fig. 2 are the particle size results from these tests with respect to the oxidation temperature. As can be seen, particle size increases with increasing temperature similar to previous investigators [6-8]. Particle size measurements were performed following testing by sieving the declad fuel and quantifying the material passing a 325 mesh screen $(45 \mu \mathrm{m})$. The variation of particle size with temperature is most likely due to agglomeration effects at higher temperatures [9]. 


\section{III.B. Decladding Efficiency}

Complete separation of the fuel from the cladding is achieved with an oxidation at $500^{\circ} \mathrm{C}$ for at least 2 hours. Gravimetric measurements, visual observations, and clad sampling have confirmed the separation efficiency. Neither air nor oxygen gas makes a difference in the separation conditions. As a note, one test was performed to $800^{\circ} \mathrm{C}$ with oxygen that resulted in oxidation of the cladding and thus, difficulty in the determination of fuel separation.

\section{III.C. Fission Product Removal Efficiency}

Sixteen fission products elements, as well as three transuranic elements, have been analyzed routinely during the test program to assess their removal efficiencies. Of these nineteen elements, only six, all fission products, have been removed to any extent during the oxidations. Removal data for the six fission products (rhodium, ruthenium, technetium, molybdenum, tellurium, and cesium) are presented with respect to temperature, pressure, oxidative gas, and cladding. A thorough description of the chemical oxidation behavior and probable species for the six fission products has been documented [10].

The amount of rhodium, ruthenium, and technetium, molybdenum, tellurium, and cesium removed during the oxidation of spent fuel is shown in Fig. 3 for a wide range of temperatures. For cesium and technetium, the isotopes Cs-137 and Tc-99 are analytically detected and assumed representative of the elements. Following the oxidation cycle described, heating continues to the temperatures greater than $700^{\circ} \mathrm{C}$.

The general trend for removal efficiencies is increasing with temperature although a few 
exceptions abound due to other factors which will be discussed. Molybdenum has been the only fission product not removed when vacuum conditions are not applied. The primary route for removal of these six fission products is by the evaporation of volatile species following the oxidation cycle [10]. Potential explanations for removals less than $100 \%$ include: partial vaporization of the gaseous species, incomplete oxidation to the volatile species, or the formation of non-volatile complex oxides.

Given in Fig. 4 are removal data for five of the six fission products at $950^{\circ} \mathrm{C}$ both with and without vacuum conditions. The calculation of removal data for rhodium was not possible due to the high analytical detection limits for these particular tests. For both tests, air was supplied during the oxidation cycle to $500^{\circ} \mathrm{C}$ then either discontinued or evacuated for the remainder of the test.

In every case, the removal of fission products is enhanced by vacuum conditions with the most significant improvement being for technetium. For cesium with a vacuum, similar removals have been observed [8]. Molybdenum was not removed without vacuum at $950^{\circ} \mathrm{C}$ due to the vapor pressure of its oxide species [10]. As a further endorsement of vacuum conditions, an additional test at $1045^{\circ} \mathrm{C}$ was performed and the removal of cesium and molybdenum was increased to $99 \%$ and $82 \%$, respectively.

Fig. 5 shows the effect of oxidant gas on removals for four of the six fission products. For these tests, vacuum conditions were not applied so molybdenum was not removed and rhodium detection was once again problematic. Both tests were performed to $950^{\circ} \mathrm{C}$ after the oxidation cycle at $500^{\circ} \mathrm{C}$.

The removal of technetium and ruthenium is increased by using pure oxygen instead of air for the oxidant cycle. The most reasonable explanation for this is the kinetics of oxidation when using pure oxygen instead of air with considerably less oxygen. On the other hand, the removal of 
cesium and tellurium decreases with oxygen due to the likely formation of involatile complex oxides species [10].

The application or timing of oxidant during testing has also been varied as shown in Fig. 6. Both tests were taken to $700^{\circ} \mathrm{C}$, although oxygen was supplied for the entire run for one test and only at the maximum temperature for the other test. Molybdenum was not removed during these tests since vacuum conditions did not exist.

The effect of oxidant timing on fission product removal is quite noticeable for tellurium, rhodium, technetium, and ruthenium and not as apparent for cesium. For the test that applied oxidant the entire run, a maximum oxidation rate of the uranium is actually occurring near $500^{\circ} \mathrm{C}$ due to phase equilibria and sintering effects above $500^{\circ} \mathrm{C}$ [9]. Thermodynamically, it would be expected that the formation and subsequent removal of volatile species, particularly $\mathrm{Tc}_{2} \mathrm{O}_{7}$ and $\mathrm{RuO}_{4}$, would be increased by applying oxidant for a longer period of time. The actual removals are less for oxidant the entire run and may be explained by the following mechanisms. The smaller particles resulting from an oxidation near $500^{\circ} \mathrm{C}$ are either being sintered as temperature is increased or further oxidized to complex (two metal) oxides, both of which would preclude fission product removal.

The effect of cladding on removal is depicted in Fig. 7 for five of the six fission products. The exclusion of rhodium data has been explained previously. Following oxidation of the spent oxide fuel at $500^{\circ} \mathrm{C}$ with air, fuel was separated from cladding for one of the tests while for the other it was not. Both tests were taken to $950^{\circ} \mathrm{C}$ under vacuum conditions to assess the effects of cladding on fission product removal.

Removal of fission products generally increases by decladding the fuel prior to the high temperature and vacuum applications with the exception of molybdenum. The discrepancy with 
molybdenum is not easily explainable but may be attributed to incomplete dissolution of samples submitted for chemical analyses, a volatile cladding reaction product, or perhaps just contamination during testing.

\section{CONCLUSIONS}

Based on tests performed to date, operating conditions have been investigated for the separation of spent oxide fuel from cladding and the variability of particle size. Complete separation of the fuel can be achieved with either air or oxygen at $500^{\circ} \mathrm{C}$ with a 2 hour hold and $2.5 \mathrm{~cm}$ segments. If the containment of fuel particles following oxidation is important, e.g. in a hot cell environment, then the oxidation cycle should be performed at a temperature high enough to maximize particle size while not oxidizing the cladding.

The following statements summarize the removal of fission products during oxidation testing on spent oxide fuel:

- Increasing temperature generally increases the removal of fission products due to the volatility of their oxidic species.

- Vacuum conditions enhance the removal of fission products, particularly cesium and molybdenum.

- The effect of oxidative gas on the removal of fission products can be both advantageous as well as detrimental depending on the fission product of interest.

- Fission product removal can be increased by applying oxidant at temperatures greater than $500^{\circ} \mathrm{C}$. 
- Separation of the cladding from spent oxide fuel prior to high temperature and vacuum conditions increases the removal of fission products with the exception of molybdenum.

\section{ACKNOWLEDGMENTS}

The authors would like to acknowledge the HFEF operations and analytical laboratory personnel for their contributions to the testing program. Work supported by the U.S. Department of Energy, Office of Nuclear Energy, Science, and Technology, under DOE-NE Idaho Operations Office Contract DE-AC07-05ID14517.

\section{REFERENCES}

1. B.R. WESTPHAL, K.J. BATEMAN, R.P. LIND, K.L. HOWDEN, K.M. GOFF, G.D. DEL CUL, B.B. SPENCER, and E.D. COLLINS "Results of Phase I Testing for the DEOX Process," Trans. Am. Nucl. Soc., 91, 519 (2004).

2. G.D. DEL CUL, R. HUNT, B.B. SPENCER, E.D. COLLINS, K. BATEMAN, K. HOWDEN, and B. WESTPHAL, “Advanced Head-End Processing of Spent Fuel: A Progress Report,” Trans. Am. Nucl. Soc., 91, 507 (2004).

3. G.E. BRAND and E.W. MURBACH, "Pyrochemical Reprocessing of $\mathrm{UO}_{2}$ by AIROX: Summary Report,”NAA-SR-11389, Atomics International (1965).

4. J.E. BODINE, I.J. GROCE, J. GUON, and L.A. HANSON, "Oxidative Decladding of Uranium Oxide Fuels," Nucl. Sci. Eng., 19, 1 (1964).

5. K.J. BATEMAN, B.R. WESTPHAL, and M.A. STAWICKI, "Experimental Equipment Design 
and Testing of the DEOX Process," Proc. $12^{\text {th }}$ Int. Conf. Nucl. Eng. (ICONE), Arlingtion, VA, April 25-29, 2004, American Society of Mechanical Engineers (2004).

6. Z. LIU, D.S. COX, R.D. BARRAND, and C.E.L. HUNT, "Particle Size Distributions of $\mathrm{U}_{3} \mathrm{O}_{8}$ Produced by Oxidations in Air at $300-900^{\circ}$ C," Proc. $13^{\text {th }}$ Conf. Can. Nucl. Soc., New Brunswick, Canada, June 7-10, 1992, Canadian Nuclear Society (1992).

7. M. IWASAKI, T. SAKURAI, N. ISHIKAWA, and Y. KOBAYASHI, "Oxidation of $\mathrm{UO}_{2}$ Pellets in Air," J. Nucl. Sci. Tech., 5 (12), 48 (1968).

8. Y. KOSAKA, K. ITOH, H. KITAO, Y. MORI, T. SHIMADA, H. YAMATOYA, K. SUTOU, and O. AMANO, "A Study on the Dry Pyrochemical Technique for the Oxide Fuel Decladding," $J$. Nucl. Sci. Tech.., Suppl. 3 (2002).

9. R.C. HOYT, L.F. GRANTHAM, R.G. CLARK, P.W. TWICHELL, “Airox Dry Processing of Uranium Oxide Fuels,” ESG-DOE-13276, Rockwell International (1979).

10. B.R. WESTPHAL, K.J. BATEMAN, R.P. LIND, K.L. HOWDEN, and G.D. DEL CUL, "Fission Product Removal from Spent Oxide Fuel by Head-End Processing," Proc. Global 2005, Tsukuba, Japan, October 9-13, 2005, Atomic Energy Society of Japan (2005). 
Fig. 1. Experimental Equipment for Irradiated Testing

Fig. 2. Particle Size Fraction versus Oxidation Temperature

Fig. 3. Effect of Temperature on Fission Product Removal

Fig. 4. Effect of Vacuum on Fission Product Removal

Fig. 5. Effect of Oxidant Gas on Fission Product Removal

Fig. 6. Effect of Oxidant Timing on Fission Product Removal

Fig. 7. Effect of Cladding on Fission Product Removal 


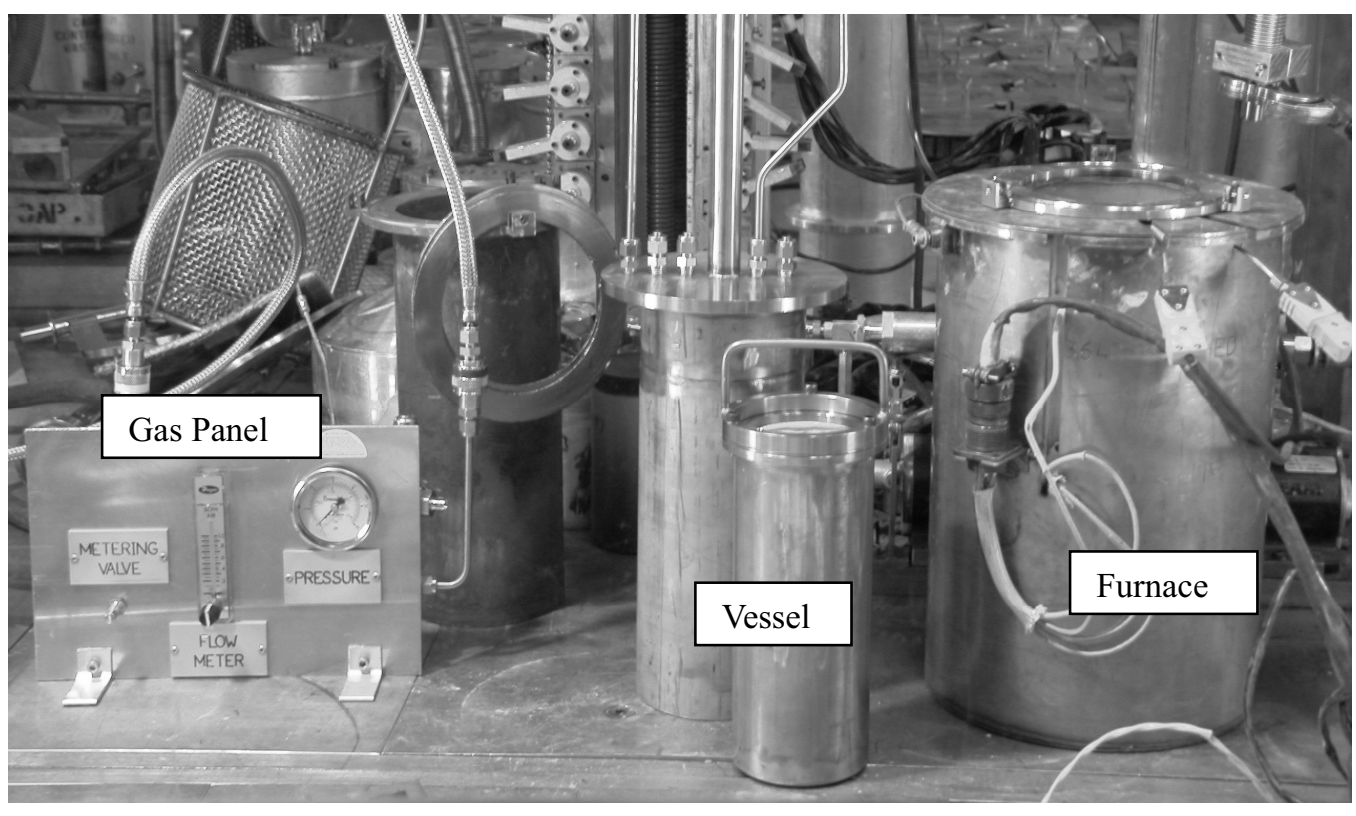

Fig. 1 


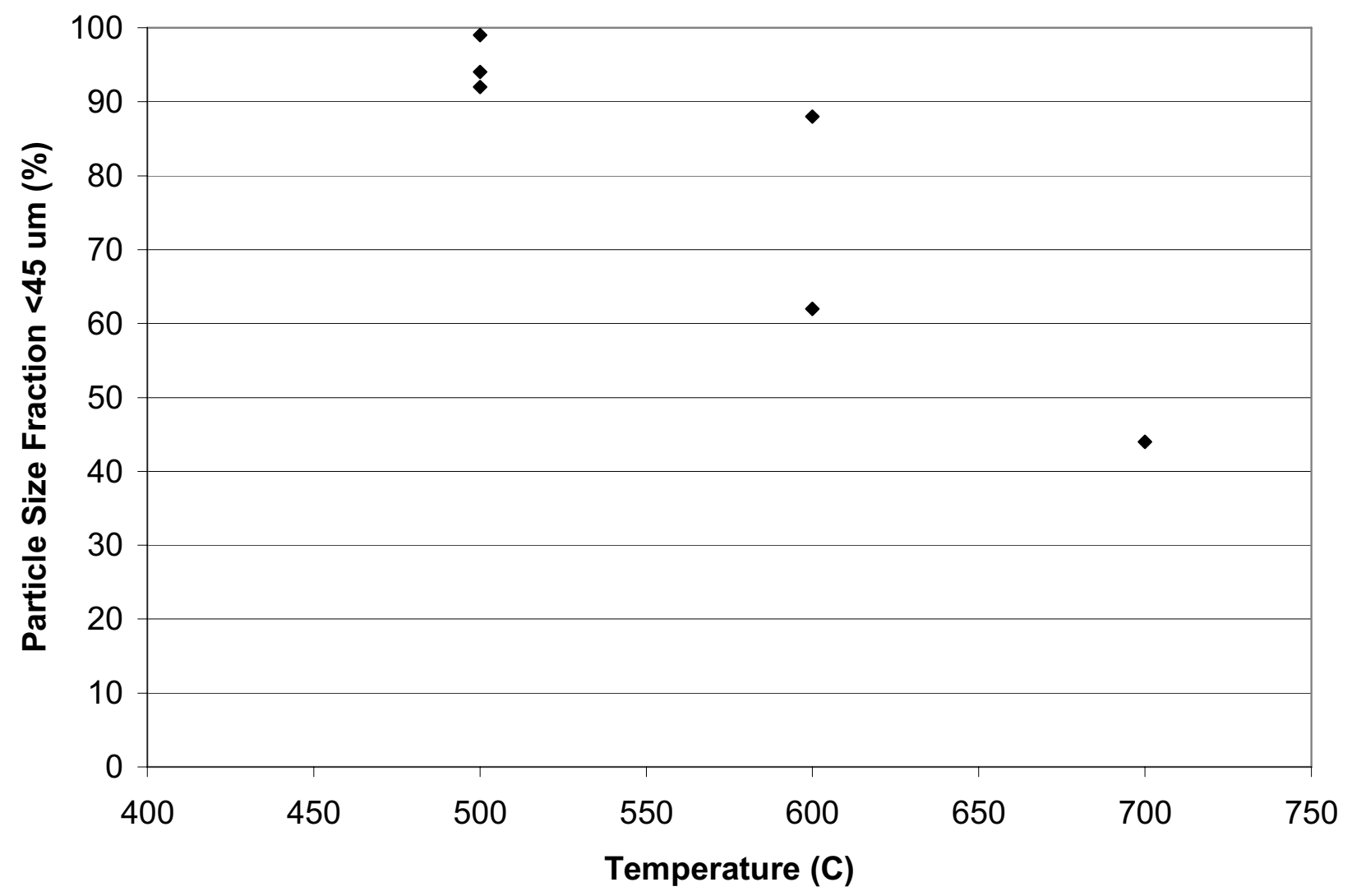

Fig. 2 


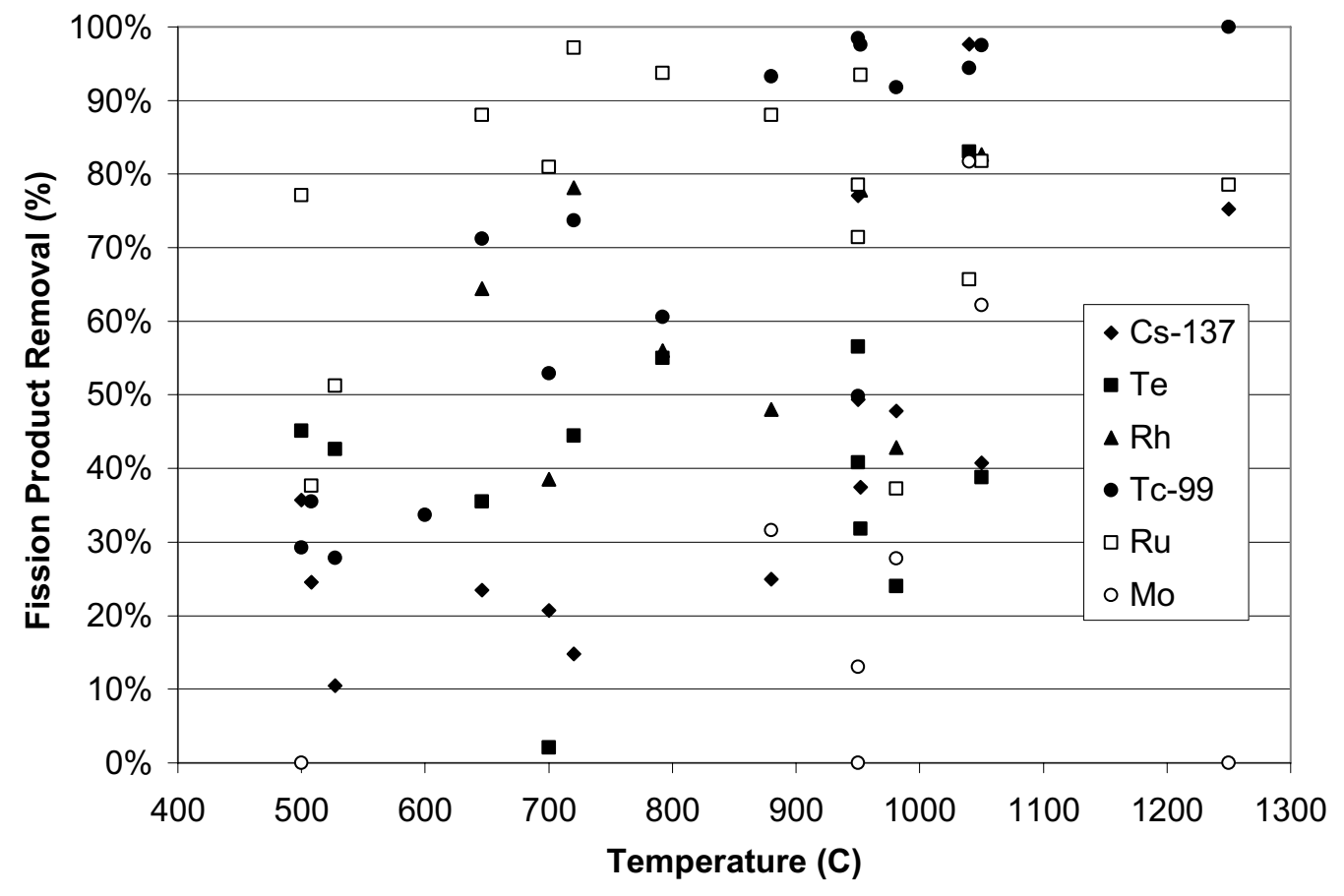

Fig. 3 


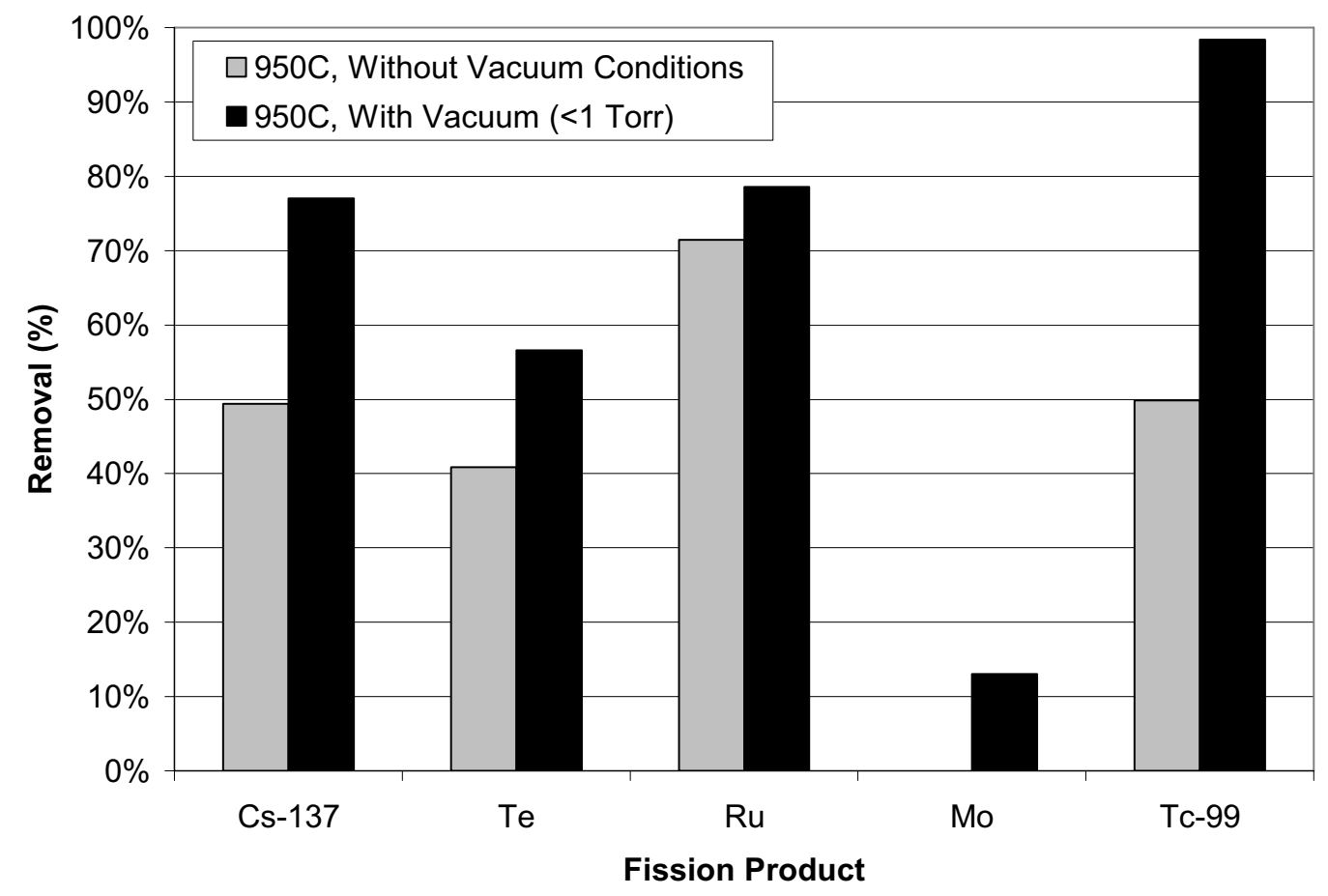

Fig. 4 


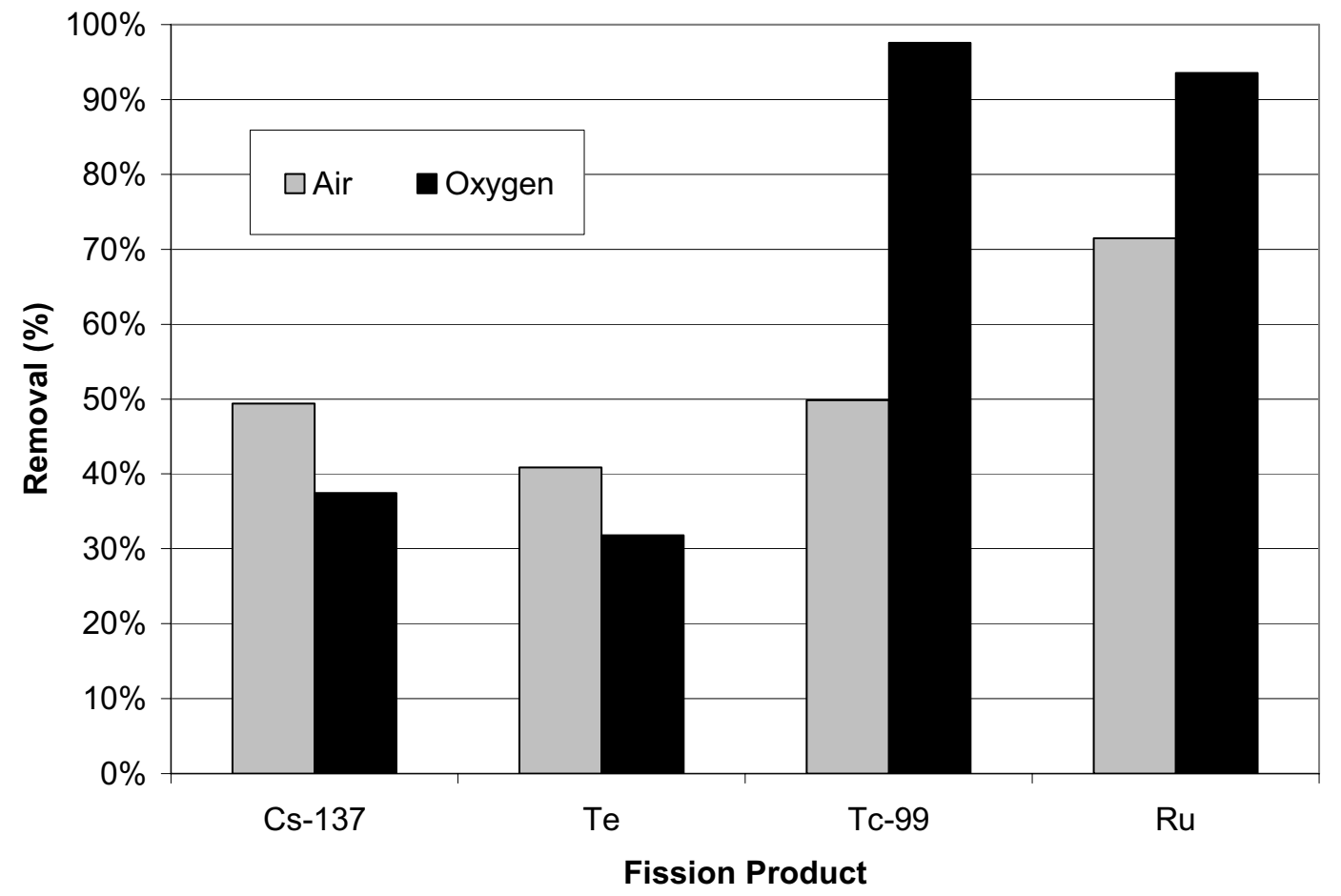

Fig. 5 


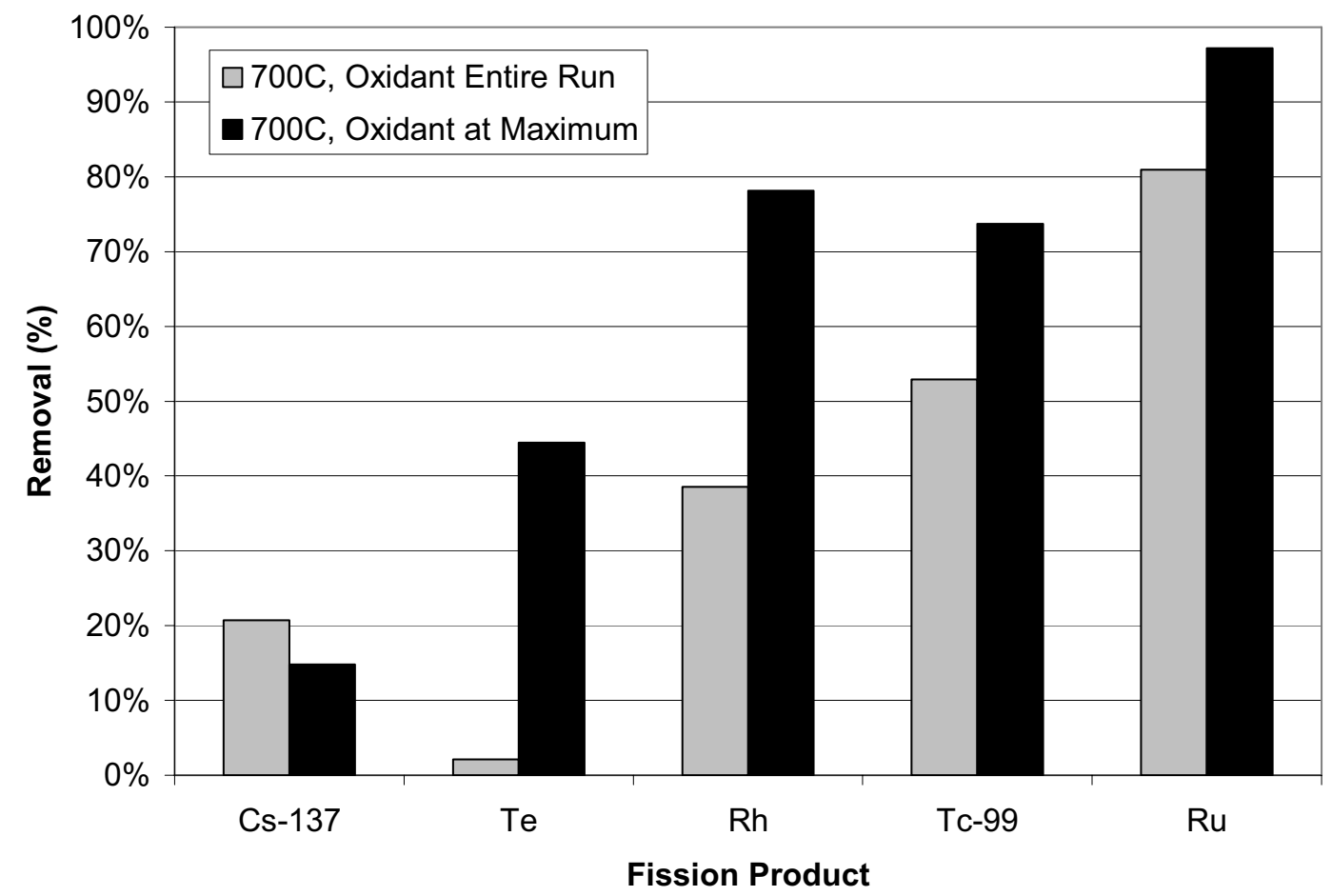

Fig. 6 


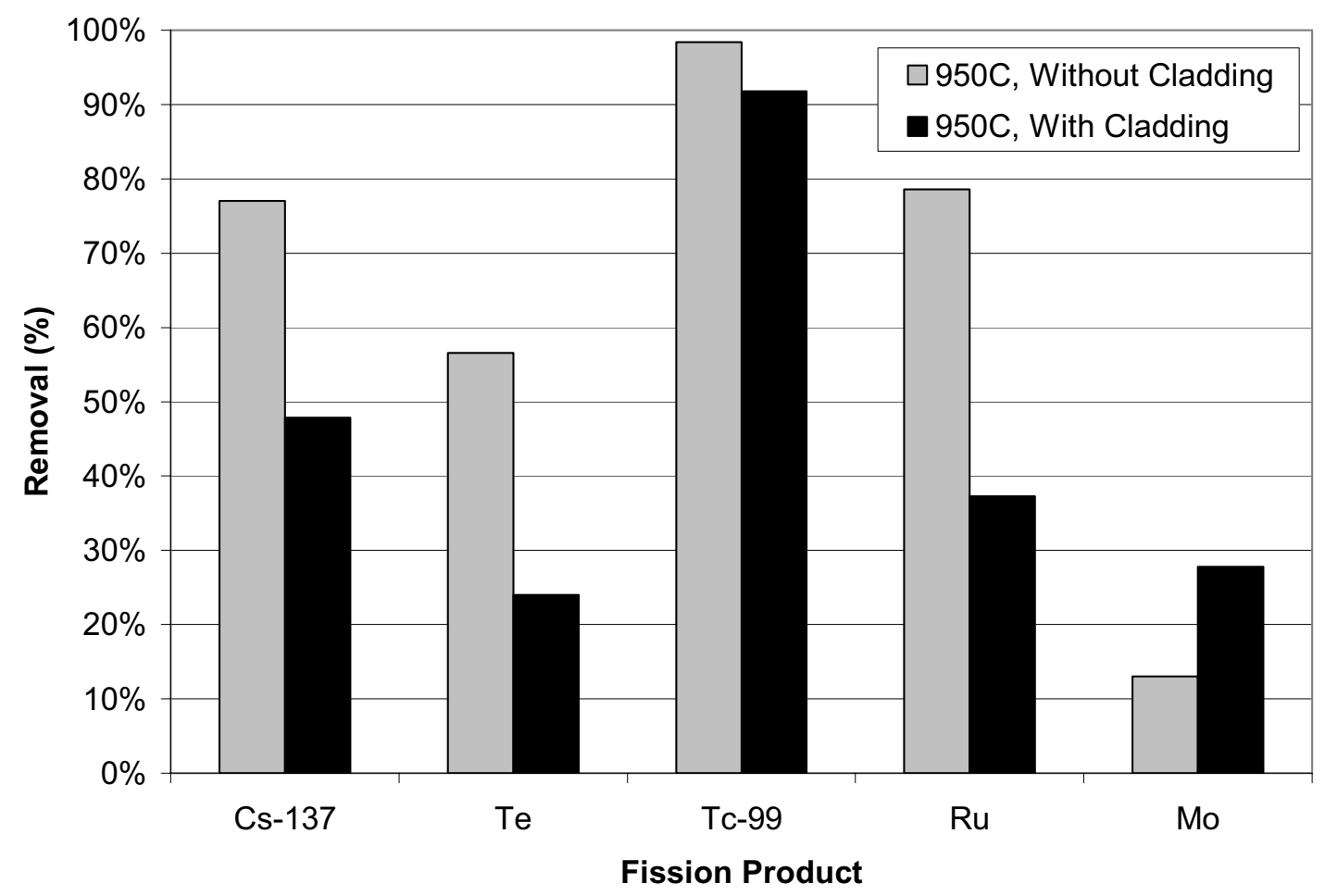

Fig. 7 